\title{
Defacing Women: The Gendering of Disfigurement
}

The discussion of disfigurement in early medieval Europe has so far mostly explored cases of men becoming disfigured. This reflects one of the clear findings to emerge from the sample of over 400 instances found in the legal and narrative sources before 1200: that men make up the vast majority of cases documented, whether as victims or perpetrators of the disfiguring injuries. The minority sample of women, however, is itself interesting in that the type or form of the disfigurement they suffer as victims frequently differs from that experienced by men. For a start, almost all the cases of female disfigurement center around some perceived sexual betrayal. This may-in the written reports at least-reflect the concerns of the biblical stories that, I have suggested, underpin the ways in which medieval clerics, the authors of almost all our written material, made sense of and presented their accounts of disfigurements. Women were, in this epistemological framework, the second and secondary sex. They were not-in theory at least-permitted to have authority over men, to teach, to stray beyond their allotted role of obedient daughters, wives and mothers. In some legal codes, they had no separate legal personality from their male relatives, but were under the latters' protection. Their bodies, whether viewed through a religious or a medical lens, were weaker, colder, impaired versions of the male ideal. ${ }^{1}$ Eve's betrayal of Adam had left women with an insuperable

This chapter further develops points made at the conference European

Perspectives on Cultures of Violence, held at Leicester University in June 2013.

(C) The Author(s) 2017

P. Skinner, Living with Disfigurement in Early Medieval Europe, DOI 10.1057/978-1-137-54439-1_5 
burden to carry, perceived always as prone to curiosity, lust and deceit, unable to control themselves and yet at the same time blamed for their power to tempt men into transgression. ${ }^{2}$ Women also rarely make it into the record as writers in this early period, and when they do it seems that they draw their authority to write from pre-existing rank or religious status, trumping their gender. ${ }^{3}$ Their writing might not mirror exactly that of their male, clerical counterparts, but nor does it appear to challenge significantly the norms visible in that output.

It is important to rehearse these issues, for all that they will be familiar to anyone who has studied medieval women's or gender history, because the ideological structures shaping the medieval record become highly visible when exploring representations of the twin subjects of women as victims and as instigators of disfigurement. Women's bodies, as numerous legal frameworks reveal, were off-limits in ways that men's were not. Violence by men against women, however, has a long history. Often (and crudely) explained as the outcome of men's superior physical strength over women, and their need to control women's productive and reproductive capacity for their own benefit, discussions of gendered violence have tended to focus on specific issues such as rape, sexual assault and/or domestic abuse. ${ }^{4}$ But men were also expected to protect "their" women from such violence: hence rape (from raptus - seizure/abduction) was literally the "theft" of the woman from her menfolk (fathers, brothers, husband). An injury to a woman-as we have begun to see with the case of Theodoric's daughter, discussed in Chapter 2-was considered an insult to the honor of her menfolk, rather than to her, a principle mirrored in Lombard law on the subject. ${ }^{5}$ This reflects the world of mutilation-byproxy introduced above, and girls and women could function equally effectively as the proxies. Nowhere is this more apparent than in a tale told by Orderic Vitalis. Eustace of Breteuil, son-in-law of King Henry I of England and husband of the latter's daughter Juliana, was in dispute with Ralph Harenc over the castle of Ivry, and the two men exchanged hostages whilst the king considered Eustace's demand that the castle be returned to him. Henry sent Eustace Ralph Harenc's son, whilst Eustace sent his two (unnamed) daughters, the king's granddaughters. On the malevolent advice of Amaury of Montfort, however, Eustace took out the boy's eyes (oculos ermit) and sent him back to Ralph. Henry, in an act of breathtaking callousness, then handed over his granddaughters to Ralph so that he could take his revenge "with the permission of the angry king." Ralph not only took out their eyes, but also cut off the tips of their noses 
(nariumque summitates truncavit). The incident is used by Orderic as a prelude to Eustace and Juliana's rebellion against her father, Henry, their distress a catalyst for their actions. ${ }^{6}$ Juliana ended up being enclosed in the nunnery at Fontevrault, but we hear nothing more of the two girls. In this political tit-for-tat, however, no comment is made about Ralph's excessive revenge-going beyond blinding to literally deface Eustace's daughters. Unpacking the episode further, however, Eustace's initial mutilation of Ralph's son, while the king himself was overseeing negotiations, represents an act of defiance, betraying the trust established between the two parties by the exchange of hostages. Children, even royal children, were mere tokens in this dangerous game-recall the fact that in 994, Thietmar of Merseberg's mother had been willing to trade him to the Saxon pirates in exchange for her brother's safety. Were two girls worth less than one boy in such exchanges? Or was Ralph's total destruction of their faces, the tipping point for Eustace to go into open rebellion, recognition of their high potential worth as marriage partners? Either way, whilst Orderic recorded the sorry tale, the fact that he did not even name the girls themselves effectively effaces them from the narrative. ${ }^{7}$

\section{WOMEN “Protected”}

As Chapter 3 outlined, early medieval law codes punished injuries inflicted upon the face and body. William Ian Miller suggests that violence is largely coded male, with female violence less imaginable. ${ }^{8}$ Since the Latin in many of the legal clauses takes the gender-neutral (or, more precisely, genderinclusive masculine) formula "Si quis...alii"/"If anyone [injures the body part] of someone else," it would be reasonable to assume in fact that the detailed injury clauses were intended to apply to men and women. Indeed, Jinty Nelson and Alice Rio have addressed precisely this issue, hypothesizing that early medieval laws did not differentiate by gender except in clauses where the injury concerned-whether shaming or physically painful or both-specifically identified the victim as female. ${ }^{9}$ Yet the genitive "alii" in the "si quis" clauses (and its more direct accusative, alium) is a grammatically different element from quis, since it implies the injury done to some other male person's body, unless we assume the genderinclusive masculine to stand for male and female victims. The careful and gendered distinction between terms for male and female slaves in the same sets of laws, however, suggests that if female victims were envisaged, they might have been indicated by "aut aliaelaliam" or similar additions to the 
text. Only the Visigothic lawcode makes it clear that the provisions are intended to apply to both men and women: "tam in viris quam in feminis observande sunt." 10 This suggests that the matter was anything but clear, and that the world of interpersonal early medieval violence was conceived predominantly as one of men.

Nelson and Rio's study outlines in some detail the ways in which violence and injury against women is presented in the medieval laws, so what follows will be a brief restatement. Exploring the early legal texts, all of which date before $1000 \mathrm{CE}$, it becomes apparent in fact that women appear in very specific contexts of violent acts. Penalties are exacted for causing abortions by potions or blows, ${ }^{11}$ free women are beaten for marrying or copulating with slaves, ${ }^{12}$ rape is punished, ${ }^{13}$ and a husband was permitted to do as he wished with an adulterous wife in Visigothic law, some of the earliest extant material. ${ }^{14}$ Ripuarian and Salic laws in Francia punished grabbing a woman's hand, arm, finger or grabbing or exposing her breasts, and Lombard law in Italy extended the prohibition of touching and grabbing to "any shameful place." 15 Blocking a woman or girl's way also attracted a penalty in Frankish and Lombard laws. ${ }^{16}$ Medics were forbidden to bleed women in the absence of her close family. ${ }^{17}$ The latter three categories underline the unauthorized nature of strangers approaching and touching women's bodies, expressed also in numerous clauses about uncovering or cutting a woman's hair, particularly within her own home. ${ }^{18}$ These provisions essentially establish a no-go zone around a woman's body, reinforced and defended by the protection or mund of her male relatives. (This probably explains Adam of Bremen's detail that the pirates in 994 came ashore and stole women's earrings - a symbolic mutilation to correspond with the physical harming of the men, rather than-or in addition to-plundering the jewelry for its intrinsic value.) Invading that space, whether through unauthorized approaches and proximity (say, into a woman's house, or blocking her way) were as threatening to the woman's own reputation as to that of her family. Touching, whether sexual in nature or not, represented an unwelcome penetration, since all touching represented a sexual approach transgressing the mund in these provisions (Rosi Braidotti's image of the body as an interface again comes to mind here). ${ }^{19}$

Work on medieval violence between men, and on knightly culture in particular, emphasizes the need for an injured man to reciprocate, often equally violently, unless bought off with considerable compensation, or risk losing his honor in the eyes of others. How this honor code worked 
in cases of disfigurement among men has already been discussed in detail in previous chapters, especially Chapter 2 . Women, however, were not expected to participate in this reciprocal contest of physical prowess: female honor and reputation might well be at stake, but violence was not, it seems, part of the process of defending it (the exception being the fierce women-often mothers and wives-depicted in Norse sagas and Irish legends, who goad their menfolk into violent acts and, in some cases, undertake the violence themselves).$^{20}$ Exploring the early medieval lawcodes with a gendered eye reinforces the idea that women's place was constructed largely as passive victims of violence, if they are mentioned at all. As Ross Balzaretti has pointed out for Lombard Italy, the laws had a problem with even conceptualizing women defending their honor with violence in the same way as men. ${ }^{21}$ Irish laws, too, are particularly dismissive of fights between women. Indeed, injuries inflicted in such fights were not considered actionable. The laws go on to allow a first wife to inflict injuries on a second wife, and the latter's retaliation could take the form only of scratching, pulling hair or speaking abusively about her rival. ${ }^{22}$ Whilst scratches to the face might well leave marks, it is clear that the actual disfigurement of another woman was not being envisaged or encouraged here. In the Burgundian laws, if a woman dishonored by having her hair cut in her own home tried to reciprocate in any way, she lost the right to claim for injury. ${ }^{23}$ Much later on, the belief that women's violence did not amount to much is expressed in the thirteenth-century Assizes of the kingdom of Cyprus: here, a woman beating a man paid half the fine a male assailant would. ${ }^{24}$ The key issue here was where the violence might take place-within the Irish home, cat-fights were not thought particularly actionable-but if a woman or group of women crossed outside the boundary of their men's protection to pursue a grievance, then they were effectively rejecting the privileges that such protection brought.

The theme of female passivity in the face of violence is also represented in narrative sources. Writing a letter of advice, the eleventh-century cardinal, and later saint, Peter Damian (1007-1072) relates a story which he says was told to him by Pope Alexander II. It involves a certain Ardericus of Milan, who got into an argument with his mother at his own wedding feast when it was reported to him by one of the servants that the food was not seasoned properly. Matters came to a head when, in his fury, he struck her about the face "as only a stepson would have." Almost immediately he was afflicted with alternating pain and numbness, swelling and putrefaction in his own face, the jaw becoming deformed as pus and poison oozed 
from an abscess. It became so bad that he feared he would lose his wife (recall here that they are newlyweds). His mother, far from rejoicing in this divine punishment, in fact prayed to St Nazarius to release her son from the torment, and her wish was granted. Although Ardericus lost a chunk of bone and flesh, and was permanently disfigured, he was healed and freed from pain. ${ }^{25}$ (We do not actually learn whether his wife stayed with him, but the assumption is that she probably did.)

What is striking about Peter's account is the detail with which he packs this story of a son who was ultimately disfigured for having treated his mother so badly-a moral tale from Peter to his correspondent not to treat his mother disrespectfully. Ardericus is punished-and permanently disfigured, the most visible of punishments - for treating his apparently blameless mother with a lack of respect (inreverenter). As her face was the target of his violence, so his face becomes the site of redress. Of course, the serving of bland, unseasoned food at his wedding feast might have been construed as bringing him into disrepute as co-host of the feast, as might his mother's indignant (and presumably fairly public) response to his accusation that she was to blame. Nevertheless, the message is one of excessive violence here. Having broken the commandment to "honor thy mother and thy father," Ardericus is punished by divine justice (divina iustitia), and loses his honor both as a son and a husband. His permanently deformed face, the passage continues, acted as a sign of his human fault, albeit cured by divine mercy. But why did Ardericus think he was going to lose his wife? Was his public loss of self-control, and consequent punishment, a threat to his "face"? And were his mother's selfless prayers intended to try to "save face" by saving his physical face? Peter's suggestion that this was an issue may ultimately hark back once again to the biblical idea of male authority diminished by deformity, but the new marriage might also have been put at risk if Ardericus' bride was so disgusted by his appearance that it affected their ability to consummate the union. Earlier Lombard law, after all, had also permitted that an engagement could be broken off if the bride became leprous (lebrosa), possessed (demoniaca) or was blind in both eyes (excecata). ${ }^{26}$ Either way, this tale introduces a number of the themes to be discussed in this chapter: violence against women, the dynamics of patriarchy in male-female relationships and masculinity expressed through violence, and the participation of women (or not) in that language of violence. On the surface, Peter Damian's tale adheres to and reinforces the normative framework of male activity and female passivity: the response of the unnamed mother is not to retaliate in 
any way to the blow at the time, and because she is such a good mother (Peter draws a relatively early contrast between her actions and those of a wicked stepmother), she prays to the saint to stop the divine punishment being meted out on her son. This she achieves, underlining the idea that the correct response for women in difficulties was to turn to prayer, rather than reciprocal violence.

Relatively little academic work has been done on the female face as a site of violence in medieval Europe. This is surprising given that ideals of beauty in European culture have most often been represented using women's features (with the possible exception of the perfect young men in classical Greek statuary). Recall again the quote from Peter Damian's letter-the human fault in his story was to be shown up in a facial sign (bumanae culpae signaculum retinetur). Now, whilst medieval philosophers, in Umberto Eco's words, "had few reasons to deal with female beauty, given that they were all men of the Church and medieval moralism caused them to mistrust the pleasures of the flesh...", they nevertheless understood the power of the body as a symbol. For Thomas Aquinas, beauty emanated from integrity. ${ }^{27} \mathrm{~A}$ flawed or mutilated body, or face, was therefore a sign of some other deficiency. This has implications for how we understand women's faces as sites of violence. Visible facial injury or its aftermath, indeed any sign of having been beaten, was understood and described as shameful, a sign of weakness in a man, rather than a source of pride-the "battle-scarred hero" did not exist in real life. Early medieval lawcodes make this visual aspect of honor and shame explicit, fining injuries which could be perceived from a certain distance away, or those which left a permanent scar. ${ }^{28}$ Yet women's injuries do not appear to have been read in the same way.

Several of the injuries to women outlined in early laws, however, seem again to be symbolic rather than permanently disfiguring. Hair cutting is a case in point. Discussing corporal punishments, Guy Geltner comments that a punishment did not necessarily have to incorporate pain to be classified as "corporal," and that "penal shaving... was broadly perceived not merely as humiliating but as an outright form of mutilation." ${ }^{29}$ We have already met cases of men being shaved and tonsured as punishment, but did the removal of a women's hair signal even greater shame? Read in the light of multiple lawcodes throwing up a virtual fence around female bodies and heads, it seems that hair cutting could have as profound a symbolism as a more permanent marker of shame. This is apparent in accounts of the downfall of Byzantine empresses. Michael Psellos reports the exile of 
Empress Zoe (d. 1050) at the hands of Michael V, which included a party being sent to cut off her hair. Psellos' language here is interesting, since the disgrace of Zoe's hair being cut is equated with her death: "She was to be offered up, so to speak, as a whole burnt-offering $(\alpha \lambda \circ \kappa \alpha \rho \pi \omega \mu \alpha) \ldots$ whether to appease God or the wrath of the emperor who gave this order, I do not know." 30 Other empresses, too, whether consorts or rulers in their own right, are also recorded as having been exiled, but what is striking is that, unlike their male counterparts, prominent Byzantine women do not appear to have been blinded or otherwise mutilated permanently as part of the process of their downfall. ${ }^{31}$ This was despite some having acquired notoriety for their multiple sexual liaisons (for example, the tenth-century empress Theophano, not to be confused with the western empress Theophanu, wife of Otto III) and/or their cruelty whilst in power. Empress Zoe, for example, is presented by Psellos as having inherited a tendency to blind indiscriminately from her father, Constantine VIII. ${ }^{32}$ Why then were these powerful women left unharmed? Again we meet gendered, ideological parameters that dictated that women, although they might rule, were exceptions to the norm. Their very femaleness, which might briefly be trumped by imperial birth (Zoe and her sister Theodora were, after all, both Purple-Born), contingency (in particular a temporary lack of viable adult male to take the imperial throne, necessitating a regency such as Empress Irene's in the late eighth century) or the sexual partners they were able to ally with (Theophano is a case in point here, marrying two successive emperors and nearly securing a third), meant that they were tolerated only as long as they were able to secure strong, male allies. When the latter abandoned them, their vulnerability as women was sufficient to disbar them from future rule: confinement to a female space such as a nunnery might be considered, but usually retirement or exile was accepted as marking the end of their ambitions. It was not necessary to mutilate them, as their claim to authority was compromised already by their sex.

\section{WOMEN DEFACED}

I suggested earlier that female sexuality underpins presentations of women and punishment; laws on adultery specifically threatened to mutilate female faces of perpetrators in an apparent move away from the death of both parties. ${ }^{33}$ The female head and face, however, also feature here in an entirely different category of legal provisions. In Visigothic Spain, if a slave prostituted herself she was publicly beaten, shaved (decalvata) and 
returned to her master (a free woman was simply beaten). ${ }^{34}$ Considerable uncertainty surrounds the meaning of decalvata, however, for it could also indicate that the slave girl was scalped, a rather more violent head injury which, assuming she survived the procedure and that the injury healed, would have left a visible, permanent, bald patch of scar tissue on her head. ${ }^{35}$ Visigothic law also punished with disfigurement any Jewish woman participating in or allowing a circumcision to take place: she was to lose her nose (men doing this were castrated). Although the latter provision was part of a wider program targeted against the expansion of the Jewish community through proselytism, both of the Visigothic clauses fall into the broad category of associating women with sexuality, and punishing them accordingly. ${ }^{36}$

Yet even if the offence was not of a sexual nature, some clerical writers still saw in their female protagonists the opportunity to present all women as Jezebels. A case in point is a story of double disfigurement, recounted by Gregory of Tours, suggesting that punitive violence could be gendered. In Book IX of his history, Gregory tells the rather unlikely story of Septimina, nurse to King Childebert's children, who was implicated in a plot to persuade the king to banish his mother, Queen Brunhild, and his consort, Faileuba, from court, or to kill him by witchcraft (maleficiis). Arrested and tortured alongside one Droctulf, who had been deputed to assist her with the children, Septimina admitted that she had killed her husband with witchcraft and then become Droctulf's lover. The pair confessed to the plot and named two further accomplices (who in fact successfully denied their involvement). ${ }^{37}$ They were both severely beaten, Septimina's faced was disfigured with red-hot irons (cauteriis accensis in faciae vulnerata - note the lack of a specific Latin term), and Droctulf lost his ears and hair. Both were then sent to royal estates to do manual labor, she grinding corn for the women in the spinning and weaving room, he working in the king's vineyards. ${ }^{38}$

This case, as reported by Gregory, needs considerable unpacking to get at why Septimina and Droctulf suffered differentiated punishments. Droctulf's mutilation partly equates him with the (unnamed) conspirators against Childebert mentioned above in Chapter 4, but unlike them, he did not lose his nose, and was not let off to be an example to others. Instead, he was confined to work on the king's estate, from where he absconded once but was recaptured. His confinement here appears to be as much of a punishment as the mutilation meted out to him; his hair would, after all, grow back, and he might be able to conceal his missing ears. 
So why was the same punishment not inflicted upon Septimina? Why target her face? Remembering that the case is being reported by a clerical author, Septimina's guilt was on three counts: first, she plotted against the king (as Droctulf had), but in addition she confessed to killing her husband and taking another sexual partner and contemplating and using witchcraft. Note the emphasis on magic to get what she wants-at no point is Septimina presented as a violent woman, just a scheming witch. Gregory's language is blunt: "[she acted] out of love for Droctulf and to join with him like a prostitute/ob amorem Droctulfi ipsumque secum scorto miscere." ${ }^{39}$ Here Septimina as woman trumps Septimina as traitor, and her main asset, her face, is targeted for punishment. Thereafter she was sent to work in penal servitude in an all-female space, the genitio or gynaeceo, where cloth was made, but her role was even more menial, grinding the corn for the workers' food. Why she was not simply executed for her many crimes is open to question: perhaps her former position as a trusted nurse earned her some mercy. It remains to ask, however, why this high-profile couple was packed off (deducitur) to rural estates to work, rather than being exhibited for public ridicule, as other plotters were. The answer may simply lie in their former positions: advertising that members of the royal household could be disloyal might not have been wise. These are named figures, whereas those who had been let out "to be ridiculed" are not even named by Gregory - they were, literally, nonentities.

\section{Defacing Women}

Miller notes that women are barely present in Norbert Elias's account of the progress from medieval barbarism to a civilized society, "except as early guardians of the civilized style." 40 This would seem to set up women as a separate group, detached from, and possibly immune to, the violence exchanged between men. Early medieval narrative sources, in particular the work of Gregory of Tours in the sixth century and Einhard in the ninth, rapidly disprove that idea. For example, Gregory reports the attempted rape of an unnamed girl by Duke Amato, in which her face is punched and slapped so hard by his servants and himself that his bed is covered in her blood. As the duke falls asleep (Gregory suggests that this happens without him carrying out the rape), the girl attempts to kill him, and is only saved from the penalty for this attempted murder by his admission that he was at fault, at which point he promptly dies. ${ }^{41}$ Here, a woman slapped and punched around the face fights back, and ultimately wins out, but most women 
participating in violent acts are written up doing so indirectly. Gregory, for instance, reports the punishment of the would-be assassins of Childbert II, two clerics with poisoned daggers, sent by Queen Fredegund. Confessing to their crime, their hands, ears and noses were cut off and they were put to death, but she emerges unscathed from the episode. ${ }^{42}$ A little later, Einhard reports that a group of conspirators against Charlemagne were exiled, some having their eyes put out first. Einhard attributes the plots against the king, if not the punishments, which after all could be entirely justified by contemporary standards, to "the cruelty of Queen Fastrada," rather than to the king himself. ${ }^{43}$ The Bible provided plenty of examples of cruel or scheming women as models for medieval writers, and undue female influence on rulers was a common topos of the chronicles. Blinding as a punishment and political tool was certainly not unheard-of in Carolingian Francia, but a woman's hold over him was squarely blamed for Charles deviating from his usual "kindness and gentleness." Of course Fastrada had a hard act to follow in Charlemagne's deceased wife Hildegard, and what Einhard sees as cruelty might actually simply be the reality of being part of a large and complex family in which she was the stepmother to his existing children, as well as mother to two daughters by Charles.

Peter Damian drew a contrast, in his story of Ardericus, between the kindness of a natural mother and the hard-heartedness of a stepmother. As Pauline Stafford reminds us, early medieval mothers, particularly royal ones, fought to ensure their own children succeeded to power, and in fact the dynamics visible in Gregory's story of Septimina adhere to this model. ${ }^{44}$ Septimina was, after all, nurse to the king's existing children, and her accuser in the treason case was Faileuba, the king's concubine, who had recently given birth. Faileuba's new baby was thus a direct competitor to Septimina's charges. Disrupting their upbringing, however temporarily, was at least one way for Faileuba to create space for her own child at court, and ultimately secure her own position.

When a mother did not live up to this early medieval maternal ideal, she might be the object of particular disapproval. Such was the case of Empress Irene of Byzantium, who acted as regent for her son Constantine from 780 until he came of age c. 790 , but ruled alone after removing him from power and having him blinded in 797. Steven Runciman's rather picturesque assessment of her conveys the ambivalence of modern scholars to her actions: "In these days of Women's Liberation... whether she was, in her methods and her achievements, an ornament to the movement, is a matter of opinion." Linda Garland states that Irene had "manipulated events 
and personalities to this conclusion." 45 Even the contemporary chronicler Theophanes, understood as something of an apologist for the empress because of her support for icon-worship, describes the blinding as "cruel and grievous" and intended (unlike other political blindings) to kill the young emperor. Whether it succeeded is unclear. ${ }^{46}$ Either way, Irene's blinding of her son actually differs from some other instances not because she was his mother, but because her actions could not be justified: Constantine was not a usurper, after all, even if his attempt to rule alone could be interpreted as disrespectful to his mother. Yet Theophanes, in an earlier passage, sets Constantine up as an equally cruel ruler who, in putting down a plot by the Caesar Nicephoros (whom he blinded), also had the tongues of his four paternal uncles cut out. "God avenged this unjust deed" when Irene blinded Constantine in turn. ${ }^{47}$ Irene managed to stay in power for a further five years before being deposed in 802 and exiled to Lesbos. Notably, as in the cases of other empresses already discussed, she was neither mutilated nor blinded: despite having been called basileus/emperor on at least one coin issue, it was unnecessary to incapacitate her further.

Irene's actions expressed her power at its height. Much later, Abbot Guibert of Nogent interprets another apparently unjust action by a woman as an "exhibition of power" as well, when he discusses (but does not name) Alais, the mother of Count John of Soissons. She is reported as having ordered the tongue and eyes of a certain deacon to be cut out, but suffered divine punishment with paralysis and the loss of her own ability to speak. More horribly, the treatment that she received involved the cutting of her own tongue, which in fact hastened her death. This story needs to be set in context: Guibert, as Anna Sapir Abulafia has demonstrated, considered John and his family heretics, particularly close to the Jews of Soissons, and so his portrayal of Alais effectively martyring a servant of the church represents an [un]edifying tale. ${ }^{48}$ It is notable, however, that he credits the dowager countess with the ability to exhibit her power-perhaps this, too, was the sign of a family out of control. Yet we have relatively few examples of female "cruelty" to set alongside the innumerable episodes that involve men giving the orders.

\section{Women, Honor and Face}

Despite the occurrence of women apparently fighting back or inflicting disfiguring injuries on others, it is difficult to categorize their actions as engaging fully with the "honor culture" of medieval society. To characterize 
it as such ignores the fact that women did not, as a general rule, enjoy the "rough equality" (a striking echo of Eileen Power's famous statement) characteristic of honor-based social relationships. ${ }^{49}$ Rather, they formed part of the group that Miller has termed "those not deemed good enough to play" the honor game. ${ }^{50}$ Although he more likely was thinking in class rather than gender terms, Miller's comment is suggestive-women did not in general participate in the reciprocal rituals of defending honor through direct or indirect violence. As we have seen, female violence was regarded as aberrant, absurd. If women sought redress at all, it was in the courts, and even there they might not achieve their goals. Battered Welsh wives, for example, if their husbands had not drawn blood, might find themselves condemned for bringing the case; they were expected to be submissive, particularly to their husbands, and to know their place in the hierarchy, and challenging their husband in public disrupted this framework. ${ }^{51}$ The vulnerability of women, as we have already seen, came from the fact that their faces were, to a certain extent, symbolic of their bodily integrity. A woman or girl with a damaged face was immediately suspect, and her shame reflected upon her family and community. In targeting the physical face of a woman, whose beauty has already been noted as a cause for concern, those carrying out assaults were well aware that the resultant bruises, scars or permanent disfigurement would be interpreted by viewers as having a deeper, more damaging meaning for the victim's social status and for the standing of her menfolk.

Women's position, therefore, is much more explicable if we instead conceptualize their medieval society as governed by a "face culture," concerned with preserving the dignity of fathers, brothers, husbands and sons within their social class, and careful not to demean themselves or their families by having sexual relationships outside of marriage or with lower-status men. Motherhood afforded them some authority, as Peter Damian's letter and numerous studies on medieval mothering illustrate, ${ }^{52}$ but only over their children, and when sons were grown men they might assume the role of their mother's protector after the death of her husband. This, as Constantine and Irene found, was a relationship fraught with problems.

Licit and illicit sexual relations are central to this scheme of female agency, since it is a focus not only of legislation that prescribes the dreadful mutilation of a guilty woman's face, but also of legislation, such as that in Wales, about when a husband was permitted to beat his wife (adultery being one instance). Earlier, continental laws permitted 
a husband to kill his adulterous wife and her partner. Such provisions persisted into the later Middle Ages: a cuckolded husband in the kingdom of Cyprus could kill his adulterous wife and her lover with impunity, but was forbidden to kill one and spare the other (the law here cites an earlier ruling of King Aimery, ruler of Cyprus from 1194 and Jerusalem from 1197 till his death in 1205). ${ }^{53}$ Either way, the legal material assumes that knowledge of the adulterous relationship will become public, and this is where the mutilation of the physical face (of the woman) intersects with the preservation of the metaphorical face (of the man).

Medieval marriages, like their ancient precursors, were highly hierarchical: the husband had total dominion over his wife, and she was expected to show him submission and obedience. The influence of the Church mitigated this somewhat by demanding mutual respect. Hence an admonition issued in Charlemagne's name after 801 reinforces the wife's duty to obey: she should be "subject to her husband in all honesty and chastity, keeping herself away from fornication, favors and selfishness, as those who [indulge in] these are repugnant to God." Husbands, in return, were ordered to love their wives, and not speak dishonorably to them. ${ }^{54}$ The hierarchy of marriage demanded that the wife obey her husband and care for his reputation-his "face"-as studiously as her own (recall the Welsh law about a wife who disrespected her husband's "beard" and could be legitimately beaten for doing so). ${ }^{55}$ This explains why legal texts often condemn marriages between socially unequal partners where the woman is of higher social status than her husband (but not vice versa), for such marriages challenged the norm of male domination. If a wife showed a lack of deference, or betrayed her husband, or was even suspected of doing so, she committed a face-threatening act. Let us remind ourselves again of Cnut's law: an adulterous woman, he says, shall become "a public disgrace" and lose her nose and ears. ${ }^{56}$ But the publicity of the case, and the supposed intervention of royal justice and/or the local bishop who was to "judge sternly" if her attempt at exculpation failed, clearly had the potential not only to disgrace the woman herself, but also her husband, whose position as cuckold would have been exposed by any proceedings. The fact that he was to receive all that his wife owned seems to be related to the compensation culture that accompanied other laws. There is, predictably enough, a doublestandard at work here, for previous clauses of the code, dealing with male adulterers, fornicators, rapists and men committing incest, are punished 
by compensation and fines (in contrast to earlier Byzantine law on the same topics).${ }^{57}$ Not only did she lose her own reputation and status, but she damaged her husband's reputation and standing as well (although we have to wait till the later Middle Ages to engage with the figure of the "cuckold", so prominent and so targeted in early modern culture). ${ }^{58}$ And this, I suggest, is why her own, physical, face was seen as a legitimate target for punishment.

What responses might a facially-mutilated woman expect from her community? The association between women's sexual transgression and punishment targeted at the face had a long history. I have noted above how mutilation of the nose, or even its complete removal, was an Old Testament penalty against loose women that found its way into multiple legal codes. In Byzantium, we should note, it was threatened for sexual misdemeanors by women and men, and for incestuous as well as adulterous relationships, and in Sicily it was targeted at women who pimped their daughters. In Spain, the penalty occurs in Jewish rabbinic responsa on the adulterous wife, where the purpose of such a mutilation was set out plainly - it was to deprive the woman of the beauty with which she had wooed her lover. ${ }^{59}$ So beauty here was a threat, and needed to be made ugly to neutralize its danger. Thus Septimina's punishment-as reported above by Gregory-addressed not (or not just) her treasonous act but also her sexual history. It therefore went beyond the penalty imposed upon Droctulf (who is not, we might note, ever referred to as a fornicator). Similarly, although Cnut's laws demand that an adulterous wife be deprived of her property - a financial compensation for her husband's loss of face-they also demand the physical mutilation of the woman herself. William Ian Miller comments that here "the idea of compensation has lost out completely to ideas of punition... The point is to render her so physically repulsive that she will have sexual virtue foisted upon her and leave her so poor that no one will be inclined to overlook the disfigurement for the benefits of her property." ${ }^{60}$ Returning to Eustace's two daughters, the unevenness of Ralph's retaliation signaled the complete closing-off of their futures as wives, but the nose-cutting was also calculated as an insult to their father, who had failed to protect them. Here, then, there is a sense that destroyed beauty might well elicit disgust from a potential sexual partner, magnifying the value of taking a gendered approach to disfigurement.

Early legislators clearly had no problem with including facial mutilation of women in their laws dealing with sexual transgression. The mere threat 
of such extreme treatment was intended to terrify women into submission. What about other types of crime? The case of Septimina, ostensibly a traitor to her king but written up as a witch and a whore by Gregory, confuses the issue by inserting her infidelity to (and murder of) her husband into the plot. A much later case, however, suggests that women taken for other crimes might expect to be treated in the same way as men. An infamous, and to my knowledge unique, case features in the court records in England in the thirteenth century. In the Shropshire Eyre of 1203 we find the following case:

[Following the death of a woman slain at Lilleshall, Alice Crithecreche and others were taken for her death]. And Alice, at once after the death, fled to the county of Stafford with some of the chattels of the slain, so it is said, and was taken in that county and brought back into Shropshire and there, as the king's serjeant and many knights and lawful men of the county testify, in their presence she said, that at night she heard a tumult in the house of the slain; whereupon she came to the door and looked in, and saw through the middle of the doorway four men in the house, and they came out and caught her, and threatened to kill her unless she would conceal them; and so they gave her half the pelf that she had. And when she came before the justices in Eyre she denied all this. Therefore she has deserved death, but by way of dispensation let her eyes be torn out. The others are not suspected, therefore let them be under pledges. ${ }^{61}$

This case, which to my mind ranks as one of the most spectacular miscarriages of justice in the medieval record, ${ }^{62}$ seems to indicate that once convicted of criminality, gender had little bearing on the punishment meted out. Alice's crime, it seems, was the fact that she had fled and recanted her "confession" to being involved, and we should note that none of the four men she mentions appear to have been apprehended, nor are they named. Alice's eyes, therefore, were symbolic of much more than her apparently involuntary (if we believe her original account) entanglement with this case. They were to be taken as a means of enforcing the authority of the court, whose real targets, the violent thieves, had evaded its reach. In effect, this is yet another mutilation-by-proxy: she is the only "hostage" the court has, and so she is condemned to punishment for the much more serious actions of others. Her permanent blindness would stigmatize her for the remainder of her life, assuming she survived the procedure, but perhaps the written record (which after all took the trouble to include her 
account), and associated oral narratives, would elicit sympathy from her community rather than disapprobation.

Cases such as this (and the Eyre cases explored above in Chapter 3) underline the fact that in later medieval Europe, the incidence of records of extreme bodily and facial mutilations appears to have increased exponentially. Note here I that focus on the record-Valentin Groebner, too, highlights the increase in documentation of violence, but attributes it to a change in culture in the fourteenth-sixteenth centuries, with more monitoring and recording of behavior. ${ }^{63}$ At the same time, however, he demonstrates that the association of damaged face with loss of status maintained its hold on medieval writers such as Albertus Magnus, and cites reports of attacks on women's faces, often targeting the nose. ${ }^{64}$

\section{Behind Closed Doors}

All of the cases used thus far have featured violence done to women's faces in public arenas, whether as judicial punishments or as incidents of interpersonal violence recorded to make a moral or other point. But some of the early medieval lawcodes we have considered assumed that women remained within, or at least close to, their homes. Thus anyone entering a woman's home to injure her also challenged the authority of her menfolk: a law of King Liutprand of the Lombards addresses deliberately setting fire to another man's house in the same clause as penalizing rape ${ }^{65}$ Lombard society, of course, was one where the mundium, the legal protection of women by men, held sway more strongly than perhaps any other region of Europe. Thus her menfolk might demand compensation, but she was forbidden from taking direct action. The home, though, was not always a safe haven. Houses were accidentally or deliberately set alight in times of war (as the graphic detail on the Bayeux Tapestry of a woman fleeing her burning house with her child, complete with caption "Here a house is burnt," illustrates). Accidents with fire or sharp implements could happen within and out of doors. Such incidents do not make it into the early medieval record, although the evidence of later coroners' rolls underlines what a dangerous place a home could be for women and their children.

And the home was also the setting for domestic violence, the likely ubiquity of which is largely concealed from view unless it reached an extreme whereby the woman herself, or members of her wider family, took action through the courts. Citing work by Sara Butler, Lizabeth Johnson 
argues that in later medieval England, at least, spousal violence barely registered in the plentiful court records and coroners' rolls, and that even if it did, two-thirds of the cases were actually homicides. ${ }^{66}$ As Hannah Skoda has pointed out, using French examples, "domestic violence operates at the interface of the public and the private." 67 Of course the face, unless covered with a veil or other wrapping (and clearly covering of the head and hair was pretty ubiquitous among married women), was itself the most public site of injury: one could attempt to conceal the violence done, but this was rather more difficult than covering up wounds or bruises to the torso. Yet the disfigurement of women by their own family members, so ubiquitous among modern cases in the media, hardly figures in the medieval evidence. Medieval authors, after all, had a stake in upholding the ideal of the male protector: this is why Peter Damian's story of transgression by an ungrateful son has such value, in demonstrating where the limits lay. Hitting one's mother in the face was unacceptable behavior, a shameful act. In fact hitting any woman in the face-even the unnamed target of Duke Amato's rape-seems to cross a line that is rarely explicitly mentioned. Was the sustained attack on this girl meant to reduce her to a state similar to a whore, or does Gregory (who as we have seen does not flinch from describing the mutilation of guilty women) include this detail to indicate just how wrong Amato's act was from start to finish? Would we even have had the story if the duke himself had not dropped dead at the end of it?

\section{CONCLUSIONS}

Gender history draws much of its energy from the analysis of the historically unequal relationships between men and women, and certainly the cases of actual disfigurement discussed here seem to argue for a double-standard at work, not only in the ways in which sexual activity was regulated, but in the way that women's faces were targeted as a means of marginalizing them and taking them out of the social arena. There is unevenness in the apparent "extra" element in the way that the appearance of women's faces is altered as well as or instead of the penalties and disfigurements meted out to men. Septimina's is burnt, Eustace's daughters lose their noses as well as their eyes, exceeding the blinding handed down to Ralph's son. Theodoric's daughter is mutilated on mere suspicion. In all three cases, the women and girls are marked visibly, whether or not also impaired physically. I have argued elsewhere, and continue to maintain, that the key to understanding 
women's faces as sites of violence is to be found in the honor networks in which their menfolk participate. As Jurgen Frembgen has pointed out in the case of nose-cutting in modern Pakistan and Afghanistan, "'honor' and 'shame' are encoded in body morphology." ${ }^{68}$ Discussing modern cases in Pakistan, Frembgen describes the men's mutilation of wives or daughters as a reciprocal act within the code of honor. Yet the women in these cases are not "rough equals" either, despite Islamic law offering more protection of wives than westerners might in fact imagine; the honor being satisfied here is male honor, restoring the man's place within the male community by "imprint [ing] his power on the surface of her body." ${ }^{69}$ This is a useful way of understanding medieval violence against women's faces too: it is striking that the law of King Cnut on adulterous wives, threatening their mutilation, does nothing to penalize the male partner in the adultery. Instead, II Cnut 50 simply orders that anyone committing adultery is to pay compensation for it in proportion to the deed. ${ }^{70} \mathrm{Men}$, then, enjoyed a right to a "proportional" punishment: the punishment threatened for female adulterers, on the other hand, as almost all the cases of violence against women's faces in the evidence, was an entirely disproportionate response born out of the need to maintain "face" and masculinity.

\section{Notes}

1. Monica Green, "Bodily essences: bodies as categories of difference," in A Cultural History of the Human Body in the Medieval Age, ed. Linda Kalof (London: Bloomsbury, 2010), 149-172, explores sexual differentiation as well as other markers of difference such as disease and disability.

2. See, e.g., John Flood, Representations of Eve in Antiquity and the English Middle Ages (New York: Routledge, 2011).

3. Although the literature is vast on this topic, one of the best singlevolume works in terms of its relevance to the early Middle Ages remains Women Writers of the Middle Ages: a Critical Study of Texts from Perpetua to Marguerite Porete, ed. Peter Dronke (Cambridge: Cambridge University Press, 1984). Surprisingly, the otherwise excellent Oxford Handbook of Women and Gender in Medieval Europe, ed. Judith Bennett and Ruth Mazo Karras (Oxford: Oxford University Press, 2013) does not have a section addressing female writers, perhaps a deliberate response to their celebration in earlier work as "women" rather than "writers"? 
4. Rape: A. Musson, "Crossing boundaries: attitudes to rape in late medieval England," in Boundaries of the Law: Geography, Gender and Jurisdiction in Medieval and Early Modern Europe, ed. A. Musson (Aldershot: Ashgate, 2005), 84-101.

5. Leges Langobardorum, Rothari, c.186, ed. F. Bluhme, in MGH LL, IV, ed. G. H. Pertz (Hannover: Hahn, 1868), 44.

6. Orderic, XII.10 (VI, 210-213). On Orderic's treatment of Juliana, see Susan Johns, Noblewomen, Aristocracy and Power in the TwelfthCentury Anglo-Norman Realm (Manchester: Manchester University Press, 2003), 17-18.

7. Adam J. Kosto, Hostages in the Middle Ages (Oxford: Oxford University Press, 2012), 85 notes a rise in the number of female hostages recorded after c.1000, but comments that "gender does not seem to have been a pressing issue." I disagree: damaging elite marital plans through the retention and/or mutilation of female family members was surely a gendered strategy? See Katherine Weikert, "The princesses who might have been hostages: Margaret and Isabella of Scotland," and Gwen Seabourne, "Female hostages: definition and distinctions," both in Hostage-Taking and Hostage Situations: the Medieval Precursors of a Modern Phenomenon, ed. Matthew Bennett and Katherine Weikert (Routledge, forthcoming). Seabourne, in particular, takes issue with Kosto's claim.

8. William Ian Miller, Humiliation and other essays on Honor, Social Discomfort and Violence (Ithaca, NY: Cornell University Press, 1998), 62.

9. Janet L. Nelson and Alice Rio, "Women and laws in early medieval Europe," in Oxford Handbook of Women and Gender, 103-117, at 105.

10. Leges Visigothorum, VI.3.3, in MGH LL. Nat. Germ. I, ed. K. Zeumer (Hannover and Leipzig: Hahn, 1902), 266.

11. Leges Visigothorum, VI.3.1 and 2 (260-1); Leges Alamannorum, LXXXVIII.1, ed. K. A. Eckhardt, MGH LL nat. Germ., V.1 (Hannover: Hahn, 1966), 150; Lex Baiwariorum, XVIII, ed. E. Liber, MGH LL. nat. Germ., V.2 (Hannover: Hahn, 1926), 361.

12. Leges Visigothorum, III.2.3, 135.

13. Leges Visigothorum, III.3.1-12; Leges Burgundionum (Gundobada), XXX and XXXV, ed. L. R. de Salis, MGH LL nat. Germ., II.1 (Hannover: Hahn, 1892), 66 and 68; Leges Burgundionum (Romana), XIX, ed. de Salis, 142-3; Lex Ribvaria, 38.1, ed. 
F. Beyerle and R. Buchner, MGH LL nat. Germ., III.2 (Hannover: Hahn, 1954), 90; Pactus Legis Salicae, XIII (gang rape by three men), ed. K. Eckhardt, MGH LL nat. Germ., IV.l (Hannover: Hahn, 1962) 58 ; Lex Salica, XIV, ed. K. Eckhardt, MGH LL nat. Germ., IV.2 (Hannover: Hahn, 1959), 52; Leges Langobardorum, Liutprand 72, ed. F. Bluhme in $M G H L L$, IV, ed. G. H. Pertz (Hannover: Hahn, 1868), 136.

14. Leges Visigothorum, III.4.1 (147), III.4.3 (148).

15. Lex Ribvaria, XLIII, 96; Pactus Legis Salicae, XX.1, 83; Lex Salica, XXVI.1, 66 and XXVI.4, 68; Leges Langobardorum, Liutprand 121 [alium locum unde turpe esse potest], 158. See also ibid., Liutprand 125, 160.

16. Pactus Legis Salicae, XXXI.2, 121; Lex Salica, XXXVIII.2, 215; Leges Langobardorum, Rothari 26 and 371, 17 and 86. For more on the implications of way-blocking, see below, Chap. 5 .

17. Leges Visigothorum, XI.1.1, 400.

18. Leges Burgundionum (Gundobada), XXXIII.1-4, 67. Pactus Legis Salicae, XXIV.3 forbade the cutting of girls' hair without the consent of her parents, 90. ibid., Addition CIV, 260, brackets cutting a woman's hair with other injuries such as causing miscarriage and death.

19. William Ian Miller, Eye for an Eye (Cambridge: Cambridge University Press, 2006), 135-139, discusses this "holy" space at length, comparing mund with the Icelandic helgi. Braidotti: above, Chap. 2.

20. For example, Hallgerda encouraging Brynjolf to kill Atli in Njallsaga, c.38; and see Miller, Eye for an Eye, 69.

21. Ross Balzaretti, “These are things men do, not women': the social regulation of female violence in Langobard Italy," in Violence and Society in the Medieval West, ed. G. Halsall (Woodbridge: Boydell, 1998), 175-192, citing Leges Langobardorum, Rothari 278 (67): absurdum videtur esse, ut mulier libera, aut ancilla, quasi vir cum armis vim facere possit, and 378 (88), denying women getting injured in such fights among men any compensation for their injuries. Leges Langobardorum, Liutprand 141 (170) reiterated the prohibition of using women in fights.

22. Fergus Kelly, A Guide to Early Irish Law (Dublin: Dublin Institute for Advanced Studies, 1988), 79.

23. Leges Burgundionum (Gundobada), XXXIII.5, elaborated in XCII.1-6.

24. The Assizes of the Lusignan Kingdom of Cyprus, tr. Nicholas Coureas (Nicosia: Cyprus Research Centre, 2002), Codex I, clause 280. 
25. MGH Die Briefe in der deutschen Kaiserzeit, IV.2: Die Briefe des Petrus Damiani II, no 85, ed. K. Reindel (Munich: MGH, 1988), 458. Translation in The Letters of Peter Damian 61-90, tr. Owen J. Blum (Washington DC: Catholic University of America Press, 1998), 250-4.

26. Leges Langobardorum, Rothari 180, 42.

27. U. Eco, On Beauty, tr. A. McEwan (London: Secker and Warburg, 2004), 154 (quote). Thomas Aquinas, Summa, I, 39.8, quoted in U. Eco, On Ugliness (London: Harvill Secker, 2007), 15.

28. See above, Chap. 3.

29. Guy Geltner, Flogging Others: Corporal Punishment and Cultural Identity from Antiquity to the Present (Amsterdam: AUP, 2014), 25 .

30. Michael Psellos, Chronographia, V.23: Michele Psello, Imperatori di Bisanzio (Cronografia), ed . and tr. Salvatore Impellizari, Ugo Criscuolo and Siliva Ronchey, 2 vols (Milan: Fondazione Lorenzo Valla/Mondadori, 1984), I, 136.

31. An early exception, reported by Theophanes, is that of Martina, mother of Heraklonas, deposed in 640/1, but whilst his nose was cut off, she lost her tongue, perhaps signalling the end of her motherly advice and guidance: Theophanis Chronographia, ed. C. de Boor, 2 vols (Hildesheim: Georg Olms, 1963), AM 6133/640-1 CE. English translation: The Chronicle of Theophanes Confessor: Byzantine and Near Eastern History, AD284-813, ed. and tr. C. Mango and R. Scott with the assistance of R. Greatrex (Oxford: Clarendon Press, 1997), 475.

32. Psellos, Chronographia, VI.157.

33. Despite passages explicitly repealing the eighth-century laws of the "heretic emperors" Leo III and Constantine V in subsequent codes issued by Basil I (d. 886) and Leo VI (d. 912), the nasal mutilation of both parties in an adulterous relationship was reiterated in Leo's Novels: Les Novelles de Léon VI Le Sage, ed. and tr. P. Noailles and A. Dain (Paris: Les Belles Lettres, 1944), Novel 32, 127-129.

34. Leges Visigothorum, III.4.17, 157.

35 . Head-shaving of women for perceived and actual sexual misconduct has persisted across the centuries, from the treatment of convicts to the shaving of "horizontal collaborators" in post-World 
War II France: Shani d'Cruze and Louise A. Jackson, Women, Crime and Justice in England since 1660 (London: Palgrave Macmillan, 2009), 129; Alison M. Moore, "History, memory and trauma in photography of the tondues: visuality of the Vichy past through the silent image of women," Gender and History, 17 (2005), 657-681.

36. Leges Visigothorum, XII.3.4, 433. On the specific context of Visigothic relations with the Jews, Norman Roth, Jews, Visigoths and Muslims in Medieval Spain: Cooperation and Conflict (Leiden: Brill, 1994), especially 7-38. Note here the apparent reciprocation of damage to a penis (circumcision) by damage to a nose, and see above, Chap. 2.

37. One was the count of the stables, Sunnigisil, who would later be involved in another plot against Childebert: GT, X.19.

38. GT, IX.38.

39. Thorpe's translation, in Gregory of Tours, History of the Franks, tr. Lewis Thorpe (London: Penguin, 1974) 524-5, "whose mistress she had then become," does not do justice to Gregory's invective here.

40. William Ian Miller, The Anatomy of Disgust (Cambridge, MA: Harvard University Press, 1997), 174.

41. GT, IX.27.

42. GT, VIII.29.

43. Einhardi Vita Karoli Magni, III.20, ed. O. Holder-Egger, $M G H$ SS rerum. Germ. XXV (Hannover: Hahn, 1911), 26.

44. Pauline Stafford, "Sons and mothers: family politics in the Middle Ages," in Medieval Women: Essays presented to Professor Rosalind M. T. Hill, ed. Derek Baker (Oxford: Blackwell, 1978), 79-100.

45. Steven Runciman, "The Empress Irene the Athenian," in Medieval Women, ed. Baker, 101-118, at 101; Linda Garland, Byzantine Empresses: Women and Power in Byzantium, AD527-1204(London: Routledge, 1999), 86.

46. Theophanes, Chronographia, AM6285, tr. Mango, 649.

47. Ibid., AM6284, 642.

48. Self and Society in Medieval France: The Memoirs of Abbot Guibert of Nogent, III.16, ed. and tr. John Benton (New York: Harper and Row, 1970), 209; Anna Sapir Abulafia, "Theology and the 
commercial revolution: Guibert of Nogent, St Anselm and the Jews of northern France," in Church and City, 1000-1500: Essays in Honour of Christopher Brooke, ed. D. Abulafia, M. Franklin and M. Rubin (Cambridge: Cambridge University Press, 1992), 23-40, at 28 .

49. Angela K.-Y. Leung and Dov Cohen, "Within- and betweenculture variation: individual differences and the cultural logics of honor, face and dignity cultures," Journal of Personality and Social Psychology, 100.3 (2011): 507-526; Eileen Power, Medieval Women (Cambridge: Cambridge University Press, 1975), 34.

50. Eye for an Eye, xi.

51. L. Johnson, "Attitudes towards spousal violence in medieval Wales," Welsh History Review, 24 (2009): 81-115.

52. E.g. Motherhood, Religion and Society in Medieval Europe, ed. Conrad Leyser and Lesley Smith (Farnham: Ashgate, 2011); Pauline Stafford, Gender, Family and the Legitimation of Power (Aldershot: Ashgate, 2006); Mary Dockray-Miller, Motherhood and Mothering in Anglo-Saxon England (New York: Palgrave, 2000); Patricia Skinner, “The light of my eyes': medieval motherhood in the Mediterranean", Women's History Review, 6.3 (1997): 391-410; Medieval Mothering, ed. J. Carmi Parsons and Bonnie Wheeler (New York: Garland, 1996).

53. Assizes of the Lusignan Kingdom, Codex I, 271. A striking parallel here is Chapter XXI (XIX). 8 of the almost contemporary rendering of Byzantine law for the Greek subjects of the Norman kingdom of Italy, which also forbade killing one and not the other of the adulterous couple: E. H. Freshfield, A Manual of Later Roman Law: the Ecloga ad Procheiron Mutata (Cambridge: Cambridge University Press, 1927), 139.

54. Mulier sint subiecti viri sui in omni bonitate et pudicitia, custodiant se a fornicatione et beneficiis et abaritiis, quoniam qui hec facit Deo repugnant... Vir diligant uxorem suam et inhonesta verba non dicat ei...: Additamenta ad Pippini et Karoli M. Capitularia, no 121, "Missi cuiusdam admonitio," in MGH Capitularia Regum Francorum I, ed. A. Boretius (Hanover: Hahn, 1883), 238-240, at 240.

55. See above, Chap. 2, note 54. 
56. Above, Chap. 3.

57. II Cnut: Secular Laws, 50-52, tr. D. Whitelock, English Historical Documents I: 500-1042 (rev. ed., London, Routledge, 1979), 462-3. Byzantine law: above, Chap. 3.

58. On this figure see Cuckolds, Clerics and Countrymen: Medieval French Fabliaux, ed. and tr. John DuVal and Raymond Eichmann (Fayetteville: University of Arkansas Press, 1982); Louise Mirrer, "The 'unfaithful wife' in medieval Spanish literature and law," in Medieval Crime and Social Control, ed. Barbara Hanawalt and David Wallace (Minneapolis: University of Minnesota Press, 1999), 143-155; Elizabeth Foyster, Manhood in Early Modern England: Honour, Sex and Marriage (London: Longman, 1999, repr. Oxford: Routledge, 2014), esp. 103-147 on "lost manhood."

59. Patricia Skinner, "The gendered nose and its lack: 'medieval' nosecutting and its modern manifestations," Journal of Women's History, 26.1 (2014): 45-67.

60. Miller, Eye for an Eye, 36. Miller suggests that some may have taken pleasure in such cruelty.

61. Select Pleas of the Crown, I: AD 1200-1225, ed. F. W. Maitland (London: Bernard Quaritch for the Selden Society, 1888), 33-34.

62. It is mentioned without comment by Edward Wheatley, Stumbling Blocks before the Blind: Medieval Constructions of a Disability (Ann Arbor: University of Michigan Press, 2010), 36-7.

63. Valentin Groebner, Defaced: the Visual Culture of Violence in the Late Middle Ages (New York: Zone, 2004), 15.

64. Ibid., 75-6.

65. Leges Langobardorum, Liutprand 72.

66. Johnson, "Attitudes towards spousal violence," 86, citing S. M. Butler, The Language of Abuse: Marital Violence in Later Medieval England (Leiden and Boston: Brill, 2007).

67. Hannah Skoda, Medieval Violence: Physical Brutality in Northern France, 1270-1330 (Oxford: Oxford University Press, 2013), 194. Her magisterial study of domestic violence, ibid., 193-230, draws a stark contrast between the unambivalent punishment of women who beat their husbands and the reluctance of the authorities to intervene when it was the husband beating his wife. 
68. J. W. Frembgen, "Honour, shame and bodily mutilation: cutting off the nose among tribal societies in Pakistan," Journal of the Royal Asiatic Society 16.3 (2006): 243-60, at 243.

69. Ibid., 252.

70. II Cnut 50, in Whitelock, English Historical Documents I, 462.

Open Access This chapter is distributed under the terms of the Creative Commons Attribution 4.0 International License (http://creativecommons.org/licenses/by/4.0/), which permits use, duplication, adaptation, distribution and reproduction in any medium or format, as long as you give appropriate credit to the original author(s) and the source, provide a link to the Creative Commons license and indicate if changes were made.

The images or other third party material in this book are included in the work's Creative Commons license, unless indicated otherwise in the credit line; if such material is not included in the work's Creative Commons license and the respective action is not permitted by statutory regulation, users will need to obtain permission from the license holder to duplicate, adapt or reproduce the material.

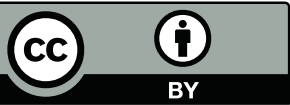

